\title{
Mispronunciation and Substitution of Mid-high Front and Back Hausa Vowels by Yorùbá Native Speakers
}

\author{
Sale Maikanti ${ }^{1}$, Yap Ngee Thai ${ }^{2}$, Jürgen Martin Burkhardt ${ }^{3}$, Yong Mei Fung ${ }^{4}$, Salina Binti \\ Husain ${ }^{5}$ \& Olúwadọrọ Jacob Oludare ${ }^{6}$ \\ 1, 2, 4, 5 Universiti Putra Malaysia, Serdang. Malaysia \\ ${ }^{3}$ Sunway University, Selangor. Malaysia \\ ${ }^{6}$ University of Ibadan, Oyo. Nigeria \\ yong@upm.edu.my
}

\begin{abstract}
Received : 2021-02-06
Revised : 2021-04-14

Accepted : 2021-04-18
\end{abstract}

ABSTRACT HISTORY

\section{KEYWORDS}

\section{Front}

Back

Vowels

Hausa

Yorùbá

\section{Introduction}

Despite the government's efforts to encourage the learning of Hausa as a second language in the college of the education system in Nigeria, there are concerns over the number of Yorùbá native speakers learning Hausa as a second language who mispronounce certain Hausa words through incorrect vowel substitutions. This poses many learning difficulties with pedagogical implications to the learners, teachers, language experts and other stakeholders in the education sector in Nigeria. Hence there is a need to identify and address such problems for language survival and development. Teachers in the area of phonetics and phonology, and second language learning are well-trained and able to understand and assist students with their pronunciation difficulties. In an attempt to succeed in identifying and solving these learning challenges faced by learners of Hausa as a second language in the College of Education system in Nigeria, the pronunciation of Yorùbá native speakers concerning the mid-high, front and back Hausa vowels was compared between two different groups (level 1 and level 3) who were studying Hausa as a second language. This study sought to find out and address specific mispronunciation difficulties experienced by the Yorùbá native speakers in vowel pronunciation. The study also sought to determine the natural development between the two groups in terms of second language learning, and more specifically, to improve the learning of Hausa vowels in the school with a focus on problematic sounds for the beginners in level 1, as well as sounds considered difficult for the advanced group in level 3. Among the focus of the case study is to allow a researcher to investigate a "case" on individual or group of peoples' behaviour, 
organisation, and school performance (David \& Ronald, 2009; Yang, 2013; Yin, 2014). In doing so, the research would bridge the existing gap(s) in literature.

\section{Literature review}

Sloat, Hoard, \& Taylor (1978), Uzoezie (1992), Opoola (2002) considered vowel as a speech sound produced by shaping and reshaping the oral cavity, which enables the free flow of air from the lungs. In a related development, Sani (1989) said that it is a speech sound of which production does not obstruct the free flow of air, but the vibration of the vocal cords is essential. As vowel is considered a sound other than a consonant, the articulation does not involve obstruction of airflow that passes from the larynx to the oral cavity (Sani, 2005; Roach, 2002); it is seen to have been playing vital roles in a language. Meanwhile, all vowels are voiced, but not all consonants are voiced. Vowel production is determined by the position of the tongue, lips, and lower jaw, in addition to the size and shape of the mouth and pharynx.

However, as vowels are categorised as either close or open, high and low, they are also classified either as front or back, up or down. The position of the lips could also be rounded or unrounded. The length of the vowels influences the phonetic realisation of vowels and their qualities in the utterances. Short vowels are considered more open, more central, and less rounded compared to long vowels. In Hausa, for instance, short vowels are realised with the same quality as long vowels in the word-final syllable and become shorter if preceded by a glottal stop, noun or pronoun in the next preceding syllable (Caron, 2015).

Vowel length differentiates the meaning of words with the exact spelling and tone patterns in the same phonetic environment. While vowel length relates to the quantity of time taken to produce a particular vowel sound, the length of the vowel is indicated in the phonetic transcription by the use of a colon [:]. In Hausa, for instance, vowel length or vowel quantity distinguishes one word from another. There are many pairs of words in Hausa with the same tone patterns and the exact spelling in the orthography, but with different vowel length in the same phonetic environment, prompting a difference in meaning (Sani, 2005).

\subsection{Hausa and Yorùbá: A historical background}

Hausa and Yorùbá are two different languages that originated from different linguistic backgrounds. They form two out of the three major languages in Nigeria, with Hausa spoken majorly in northern Nigeria as a lingua-franca with high population density, including parts of the West African sub-region (Gordon, 2005) and Yorùbá spoke in south-western Nigeria. While Hausa is a Chadic language under the Afro-Asiatic language phylum, Yorùbá, on the other hand, is from the Niger-Congo language family. As the current population of Hausa users in Nigeria is put around $53,700,000$, that of Yorùbá is approximately 42,000,000 (Eberhard, Gary, \& Charles, 2020). Hausa is among the languages spoken as a second language in the Western world such as Great Britain, the United States of America, Germany, and China (Blench, 2014), just as Yorùbá is also spoken in countries such as Benin Republic, Togo, Republic of Cuba, and Brazil (Olusola, 2015). Speaking Yorùbá in such areas is in addition to speaking the language in some parts of the Delta, Edo, Kwara and Kogi States of Nigeria (Olúwadọrọ̀ \& Abiola, 2016). Since Yorùbá belongs to the Niger-Congo phylum of African languages, it is considered the second largest language in Nigeria after Hausa, with an estimated population of about 16 million speakers (Williamson \& Blench, 2000; Blench, 2019).

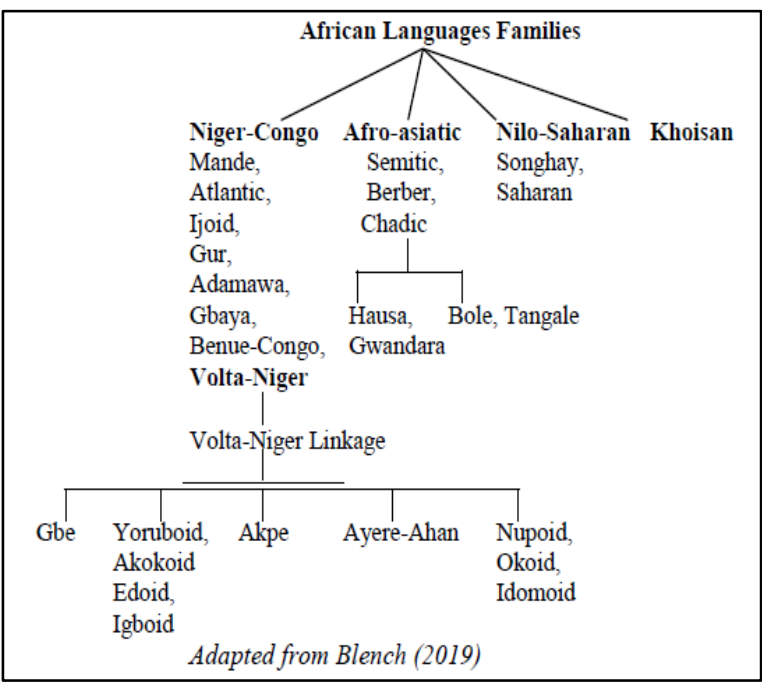

Figure 2.1 Hausa and Yorùbá Languages Family

The standard Hausa has five pairs of monophthongs comprised of 5 short vowel phonemes such as /i/[i], /e/[e], /a/[a], /o/[o], /u/[u]; 5 long vowel phonemes: /i:/[i:], /e:/[e:], /a:/[a:], /o:/[o:], /u:/[u:], and 2 diphthongs: /ai/[ai] and /au/[au] (Sani 2005, 2007). The standard Yorùbá on the other hand, has 7 oral vowel phonemes: /i/[i], /e/[e], /ẹ/[c], /a/[a], /o/[o], $/ \mathrm{o} /[\mathrm{o}], / \mathrm{u} /[\mathrm{u}]$, and 5 nasal vowel phonemes: $<\mathrm{in}>[\tilde{]}]$, $<$ ẹn $>[\tilde{\varepsilon}],<\operatorname{an}>[\tilde{a}],<o ̣ n>[\tilde{\jmath}],<u n>[\tilde{u}]$ (Arokoyo, 2012; Eme \& Uba, 2016). The short mid-high, front and back vowels /e/ and /o/ are amongst the shared vowels by Hausa and Yorùbá languages, whereas, the long mid-high, front and back vowels /e:/ and /o:/ are peculiar to only Hausa. The phonemic differences in the two languages constitute learning difficulties among Yorùbá native speakers. The present study was 
limited to the analysis of only the short and long midhigh, front, and back Hausa vowels such as /e/, /e:/, $/ \mathrm{o} /$ and $/ \mathrm{o}: /$. This was because, despite the fact that such vowel phonemes do not belong to the same group for them to be all in front or back, yet, they are mid-high vowels, and relate to each other.

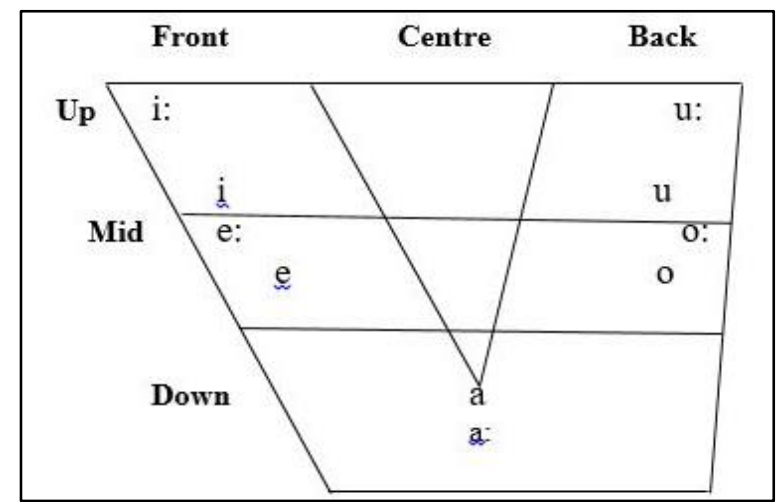

Figure 2.3 Hausa vowel chart (Adapted from Sani, 2005)

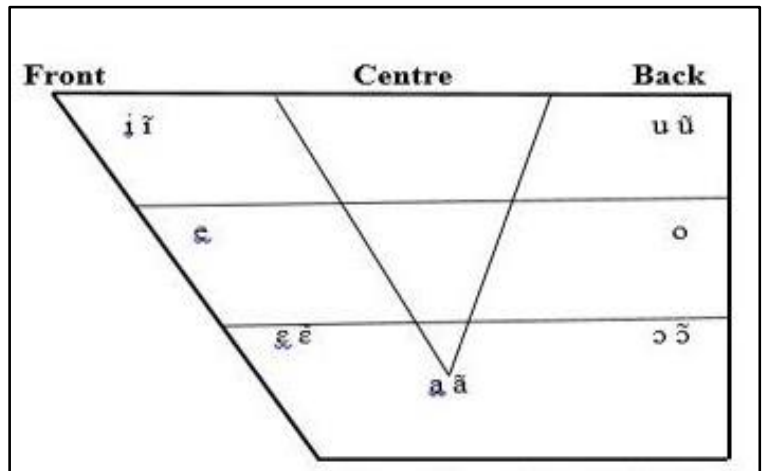

Figure 2.4 Yorùbá vowel chart (adapted from Akinola, 2014)

Despite many kinds of researches comparing Hausa with other languages (e.g. Abubakar, 2014; Ata, 2015; Abubakar, Maikanti, \& Ago, 2014; Keshavarz, \& Khamis, 2017; Mahmoud, 2017; Maiunguwa, 2015; Malah \& Rashid, 2015; Mohammed, 2011; Salisu \& Grema, 2018) as well as studies comparing Yorùbá with other languages (e.g. Adekunle, 2014; Akínkùgbé, 1978; Arokoyo, 2012; Adejubee \& Kammelu, 2010; Babarinde, 2017; Eme \& Uba, 2016; Igboanusi, 2006; Ilòrí, 2010; Ojo, 2004; Olusola, 2015), to date, studies related to mispronunciation of Hausa vowels by Yorùbá speakers have received scant attention.

Therefore, the current study intended to address the gap in Hausa learning by the Yorùbá native speakers, among other factors that triggered this research. Most studies on Hausa (e.g. Abubakar, 1999; Ata, 2015; Baba, 1998; Fagge, 2012; Jaggar, 2001; Leben, 1970; Newman, 1995; 2000; and Sani, 2005) focused on Hausa L1 grammar and phonology, paying less attention to comparative studies associated with Hausa-Yorùbá L2 learning. There is a need to fill the existing gap. Many studies (e.g. Hao, 2012; Leung, 2008; Qin \& Mok, 2013; So, 2010; So \& Best, 2010; Tao \& Guo, 2008; Wang, Jongman \& Sereno, 2003; Wong, Schwartz \& Jenkins, 2005; Wu, Munro \& Wang, 2014; Yang, 2018; and Zhang, 2007) focused on the perception of speech sounds, rather than production. Studies on perception and productions (e.g. Abdullahi, 2018; Flege, Bohn and Jang, 1997; Koerich, 2002; Maiunguwa, 2015; Yang, 2018) indicated that perception outperformed research on production. Similarly, there has been little research focussing on production alone, particularly on the pronunciation of Hausa vowels by Yorùbá native speakers for reference and documentation.

Additionally, research on second language phonology is one of the less-studied areas in recent times (Diettes \& Johanna, 2014; Thomson \& Derwing, 2015; Abdullahi, 2018). This is because learning new sounds, particularly vowels, is regarded as one of the most challenging tasks for second language learners to achieve in a short amount of time. Hence, there is a need to examine the Yorùbá native speakers' pronunciation of Hausa vowels, particularly the disyllabic Hausa words, to understand the errors committed to learning more clearly. This research is relevant to the needs and aspiration of the stakeholders in education in Nigeria because, production of Hausa vowels is characterised by errors committed by the Yorùbá native speakers, coupled with the paucity of research on pronunciation problems faced by the Yorùbá native speakers.

It is against this background that the present study compared the performance of level 1 and level 3 students on how they produced the 5 short: /i/, /e/, /a/, /o/, /u/; 5 long: /i:/, /e:/, /a:/, /o:/, /u:/, and 2 diphthongs /ai/ and /au/ Hausa vowels. This was to determine whether there was a significant difference between the short and long mid-high, front, and back Hausa vowels: /e/, /e:/, /o/ and /o:/ produced by the Yorùbá native speakers who were learning Hausa as a second language. The students in the present study attended the College of Education to study Hausa as L2 and spent at least three years to obtain the Nigeria Certificate in Education (NCE) as the minimum teaching qualification to teach at the primary or secondary school level (public or private), in the absence of trained Hausa L1 teachers (National Policy on Education, 2004; Nigeria Certificate in Education Minimum Standards for Languages, 2012).

The level 1 participants were entry-level students, whereas the level 3 participants were exit-level students preparing to graduate from the NCE program. This was to ascertain the natural development associated with language learning 
between the two identified (non-experienced vs experienced) groups. The level 2 students who were in the second year were intentionally excluded from the study to enable the researchers to draw a conclusion based on the performance of only two groups. This study aimed to improve the teaching and learning of Hausa as a second language not only in Yorùbá land but also in Igbo land, including other countries where Hausa is studied as a second language.

\section{Method}

This research employed a mixed data collection method. Both quantitative and qualitative data methods were used to examine how and why the Yorùbá native speakers mispronounced the mid-high front and back Hausa vowels when learning Hausa as a second language.

The selection of participants was based on purposive sampling. It was necessary to recruit participants who were purely Yorùbá native speakers with Yorùbá language and cultural backgrounds, who were also Hausa learners and willing to participate in the study voluntarily. A total of eighty-eight (88) participants were selected. To ensure that only the right participants were recruited for the present study, the participants were screened. This enabled the researchers to identify those who were non-native speakers of Yorùbá but could speak the language. Since case study research is not meant to be generalised, there is no universal rule concerning the number of sample selections, as this depends on the objectives of the research (Sharp et al., 2012).

One of the problems associated with learning Hausa, Igbo or Yorùbá land was related to the student's enrolment in schools. Many students do not develop much interest to study Hausa in a College of Education system compared to other courses such as Law, Medicine, Accountancy, and other professional courses. This accounted for the low enrolment number of the Yorùbá speakers in the South-West of Nigeria to learn Hausa as a second language. Of all the 88 participants recruited in this study, 40 were in level 1 , while 48 were in level 3. 48. These numbers represented the students' enrolment in all the chosen schools. While the acceptable sample size for qualitative research is between 10 to 15 , Holton and Bernett (1997) also added that "one of the real advantages of quantitative methods is their ability to use smaller groups of people to make inferences about larger groups that would be prohibitively expensive to study" (p. 71). In the case where the population is small, Creswell (2014) recommended using the entire population as the sample.

Twenty-four different wordlists comprising the target and non-target vowels extracted from Bargery's
(1934) Hausa-English dictionary and prepared in carrier phrases served as the research instrument. In the first and second syllables of Hausa words with CV.CVV and CVV.CV disyllabic forms, the 12 Hausa vowels (10 monophthongs, two diphthongs) were examined accordingly. For instance, 'Kégé' consists of short /e/ in the first syllable, while ' kágé' on the other hand involves a similar short /e/ in the second syllable. Besides, as 'bébé' has a long /e:/ in the first syllable, 'bègé' involves a similar long /e:/ in the second syllable. The fact that standard Hausa has ten monophthongs (5 short and five long vowels in addition to the two diphthongs) (Sani, 2007), every vowel was accounted for in the first and second syllables of Hausa words. All the Hausa vowels used in the stimuli were also tone marked to guide the participants in the production task. Besides, putting the wordlists in carrier phrases restricted the participants from identifying the specific items being examined by the researchers. As a result, they did not need to put extra effort into the production task.

Since the focus of this study was to investigate the mispronunciation and substitution of mid-high, front and back Hausa vowels in the first and second syllables, only words containing two syllables were selected. Meanwhile, the size of the data needed for analysis also depends on the nature of the research. The data used in this study were converted to numbers following the Migrant and Seasonal Head Start Technical Assistance Centre (2006), that numeric data for quantitative research could be large or small depending on the research focus. As the instrument's validity was to ensure that the tool measured what it was supposed to measure, it also explained how well the data collected covered the area of investigation (Field, 2005; Ghauri \& Gronhaug, 2005; Terhadoost, 2016). In ensuring that only the actual disyllabic Hausa words were used for the data collection, the wordlists used were extracted from Bargery's (1934) Hausa-English dictionary and were further reexamined by two experts (linguists) from two different universities.

The data collection took place after obtaining the necessary Ethics Approval from the authority concerned. The participants were duly informed that their participation in the research was optional. Those who agreed to participate were given a production task to perform, and enough time was given to every participant to read the wordlists aloud in a carrier phrase until they had completed the task. Since reading the stimuli could only be done once without rehearsal, a conducive atmosphere was created to perform the task in a natural and relaxed manner, while one of the researchers personally conducted the audio recordings. The production tasks and recordings were done in soundproof booths in the language 
laboratories and staff offices. The measure was to avoid interruption or unnecessary background noise that could affect the quality of the speech sounds recordings. Any form of interference with the speech production while the recording was taking place could render the data unclear and unfit to meet the desired quality of the study. Additionally, to ensure a smooth data collection process, participants were organised and allowed to enter the venue one by one to perform the task during break or lecture-free hours.

The production of 12 Hausa vowels: /i/, /i:/, /e/, /e:/, /a/, /a:/, /o/, /o:/, /u/, /u:/, and 2 diphthongs /ai/ and $/ \mathrm{au} / \mathrm{contained}$ in the pronunciation of disyllabic Hausa words by Yorùbá native speakers were audiorecorded and examined. In a language, vowels determine the pronunciation and meaning of lexical and grammatical words of that particular language (Shehu and Njidda, 2016). Besides, it was also to determine whether there were errors in pronunciation of certain Hausa disyllabic words produced by the Yorùbá native speakers. Two Hausa native speakers rated the performance of each participant. '1' mark was awarded for every correct pronunciation of the vowel in the first syllable, and '0' mark for the wrong pronunciation.

Similarly, the '1' mark was recorded for every correct pronunciation of the vowel in the second syllable and the ' 0 ' mark for the wrong pronunciation. Any missing word(s) or those which could not be pronounced correctly were given the ' 0 ' mark. While the total mean scores were used for the quantitative analysis, one of the researchers served as the third rater transcribed the speech sounds for in-debt analysis. A Mann-Whitney $U$ test was conducted to compare and determine if there was a significant difference in the performance of level 1 and level 3 participants in the production of Hausa vowels in the first and second syllables. Choosing to perform a nonparametric test for this study was that the data was not normally distributed to meet the parametric requirement. The difference between variables such as frequencies and mean scores were described using quantitative data (Hopkins, 2008).

This enabled the researchers to determine whether there was a statistical difference between the two sampling groups using the SPSS statistical tool. An analysis was carried out based on patterns of errors committed by the participants across the two groups. The relationship between two or more scores obtained from the participants in research using the same instrument has different names such as inter-observer reliability, inter-rater agreement, inter-rater concordance, and 'inter-rater reliability' (Gwet, 2008). In an attempt to determine the level of agreement between the two raters used in this study, inter-rater reliability using Pearson correlation was conducted based on the mean scores obtained by the participants, according to items on each syllable. This was to ensure the data collected correctly represent the variables measured, which shows the closer the participants' scores by different raters, the higher the reliability of the data collected (Mchugh, 2012).

\section{Findings}

\subsection{Production of /e/ and /e: / in the first syllable}

The results revealed no significant difference between the two groups in the production of mid-high short front unrounded /e/ vowel, especially in terms of their performance in the first syllable $(\mathrm{U}=820 ; p$ $>$.138). However, the mean rank indicated that the Yorùbá native speakers in level 3 performed better than their counterparts in level 1. Meanwhile, the Mann-Whitney $U$ test results indicated a significant difference between the performance of level 1 and level 3 participants in the production of mid-high long front unrounded /e:/ vowel in the first syllable $(\mathrm{U}=$ $676 ; p<.001)$. The mean rank also showed that the Yorùbá native speakers in level 3 performed much better than the Yorùbá native speakers in level 1.

Table 4.1 Mean Rank for /e/ and /e:/ in the first syllable

\begin{tabular}{clccc}
\hline \multicolumn{5}{c}{ Ranks } \\
$\begin{array}{c}\text { Hausa } \\
\text { vowels }\end{array}$ & $\begin{array}{c}\text { Group of } \\
\text { participants }\end{array}$ & N & $\begin{array}{c}\text { Mean } \\
\text { scores }\end{array}$ & $\begin{array}{c}\text { Sum of } \\
\text { Ranks }\end{array}$ \\
\hline Short /e/ & Level 1 & 40 & 41.00 & 1640.00 \\
& Level 3 & 48 & 47.42 & 2276.00 \\
& Total & 88 & & \\
& & & & \\
Long /e:/ & Level 1 & 40 & 37.40 & 1496.00 \\
& & 48 & 50.42 & 2420.00 \\
& Level 3 & 88 & & \\
\hline
\end{tabular}

The results presented in Table 4.1 disclosed that the mean ranks for the production of /e/ and /e:/ by level 3 participants in the first syllable were better than the performance of level 1 participants.

\subsection{Production of $/ 0 /$ and $/ 0$ :/ in the first syllable}

The Mann-Whitney $U$ test conducted indicated no significant difference in the performance of level 1 and level 3 participants in the production of mid-high short back vowel /o/ in the first syllable $(\mathrm{U}=768 ; p$ $>.063$ ). However, the mean rank revealed that Yorùbá 
native speakers in level 1 performed much better than the Yorùbá native speakers in level 3. The performance of the two groups was also compared using a Mann-Whitney U test, and the result pointed out a significant difference in the production of the mid-high long back vowel /o:/ in the first syllable (U $=724 ; p$ <.006). The mean rank, therefore, revealed that the Yorùbá native speakers in level 3 did better than the Yorùbá native speakers in level 1.

Table 4.2 Mean Rank for /o/ and /o:/ in the first syllable

\begin{tabular}{ccccc}
\hline $\begin{array}{c}\text { Hausa } \\
\text { vowels }\end{array}$ & $\begin{array}{c}\text { Group of } \\
\text { participants }\end{array}$ & N & $\begin{array}{c}\text { Mean } \\
\text { scores }\end{array}$ & $\begin{array}{c}\text { Sum of } \\
\text { Ranks }\end{array}$ \\
\hline \multirow{3}{*}{ Short /o/ } & Level 1 & 40 & 49.30 & 1972.00 \\
& Level 3 & 48 & 40.50 & 1944.00 \\
& Total & 88 & & \\
& & & & \\
Long /o:/ & Level 1 & 40 & 38.60 & 1544.00 \\
& Level 3 & 48 & 49.42 & 2372.00 \\
& Total & 88 & & \\
\hline
\end{tabular}

Table 4.2 contains the results indicating that, while the mean rank for the production of $/ \mathrm{o} /$ in the first syllable by the participants in level 1 was better than the performance of level 3 , the mean rank for the production of /o:/ by the participants in level 3 was, better than that of level 1 .

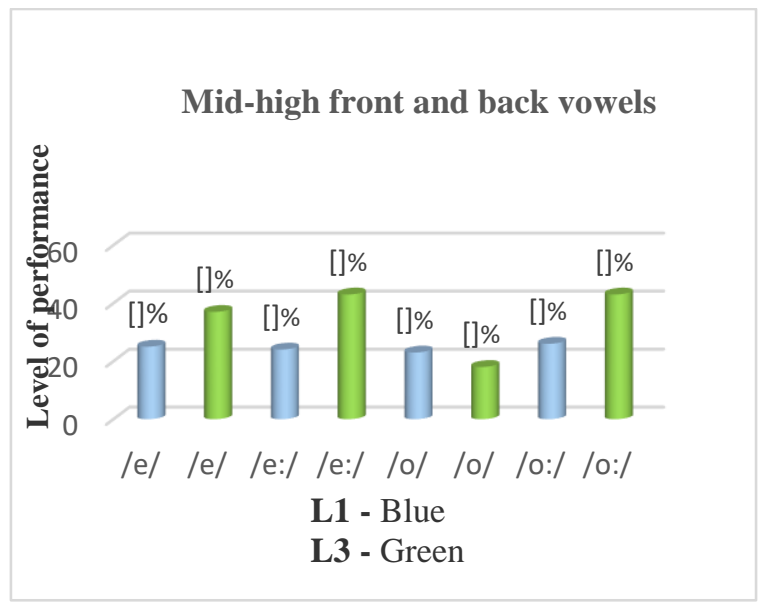

Figure 4.1 Level of performance in the first syllable

Figure 4.1 shows the level of performance of the participants in level 1 and level 3 in general.

\subsection{Production of /e/ and /e:/ in the second syllable}

The results of the Mann-Whitney U test displayed a statistically significant difference in the production of mid-high short front unrounded /e/ in the second syllable $(\mathrm{U}=628 ; p<.001)$ between the two groups. The mean rank revealed that the Yorùbá native speakers in level 3 performed significantly better than the Yorùbá native speakers in level 1. The MannWhitney $U$ test comparing the two groups demonstrated that there was a statistically significant difference in the performance of level 1 and level 3 participants in the production of mid-high long /e:/ in the second syllable $(\mathrm{U}=756 ; p<.007)$. The mean rank revealed that the Yorùbá native speakers in level 3 did better than the Yorùbá native speakers in level 1.

Table 4.3 Mean Rank for /e/ and /e:/ in the second syllable

\begin{tabular}{ccccc}
\hline Hausa & \multicolumn{3}{c}{ Ranks } & \\
vowels & $\begin{array}{c}\text { Group of } \\
\text { participants }\end{array}$ & $\mathrm{N}$ & $\begin{array}{c}\text { Mean } \\
\text { scores }\end{array}$ & $\begin{array}{c}\text { Sum of } \\
\text { Ranks }\end{array}$ \\
\hline Short /e/ & Level 1 & 40 & 36.20 & 1448.00 \\
& Level 3 & 48 & 51.42 & 2468.00 \\
& Total & 88 & & \\
& & & & 1576.00 \\
Long /e:/ & Level 1 & 40 & 39.40 & 2340.00 \\
& Level 3 & 48 & 48.75 & \\
\hline
\end{tabular}

As illustrated in Table 4.3, the results revealed that the mean ranks for the production of /e/ and /e:/ by the participants in level 3 in the second syllable were better than the performance of their counterparts in level 1 .

\subsection{Production of /o/ and /o:/ in the second syllable}

The Mann-Whitney U test revealed that there was no significant difference in the production of midhigh short back vowel /o/ in the second syllable ( $\mathrm{U}=$ $780 ; p>.075$ ) between level 1 and level 3 participants. The mean rank indicated that the Yorùbá native speakers in level 3 performed better than the Yorùbá native speakers in level 1 . The results of the MannWhitney U test also stated that there was a statistically significant difference in the production of mid-high long back vowel /o:/ in the second syllable $(U=832$; $p<.041)$ between the two groups. The mean rank indicated that the Yorùbá native speakers in level 3 performed better than the Yorùbá native speakers in level 1.

Table 4.4 Mean Rank for /o/ and /o:/ in the second syllable

\begin{tabular}{ccccc}
\hline \multicolumn{5}{c}{ Ranks } \\
$\begin{array}{c}\text { Hausa } \\
\text { vowels }\end{array}$ & $\begin{array}{c}\text { Group of } \\
\text { participants }\end{array}$ & N & $\begin{array}{c}\text { Mean } \\
\text { scores }\end{array}$ & $\begin{array}{c}\text { Sum of } \\
\text { Ranks }\end{array}$ \\
\hline Short /o/ & Level 1 & 40 & 40.00 & 1600.00 \\
\hline
\end{tabular}




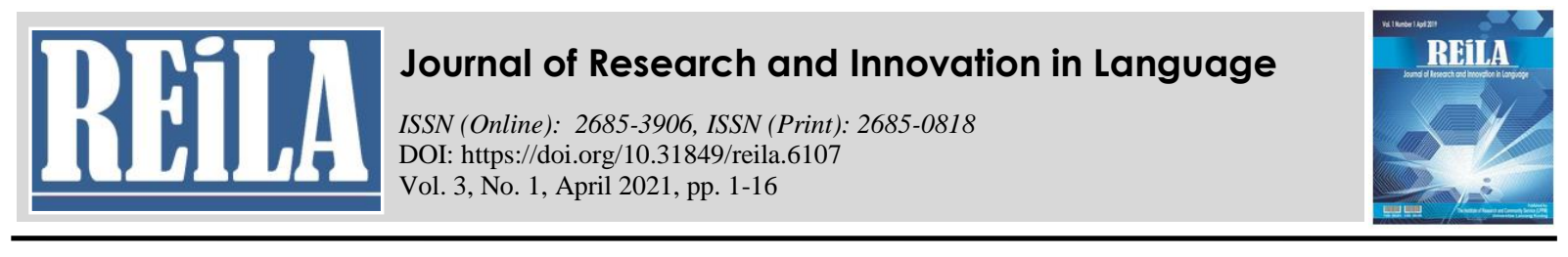

\begin{tabular}{ccccc}
\hline & Level 3 & 48 & 48.25 & 2316.00 \\
Total & 88 & & \\
& & & & \\
& Level 1 & 40 & 41.30 & 1652.00 \\
Long /o:/ & Level 3 & 48 & 47.17 & 2264.00 \\
& Total & 88 & & \\
\hline
\end{tabular}

The table 4.4 displays the mean ranks for the production of /o/ and /o:/ vowels by the participants in level 1 and level 3 in the second syllable.

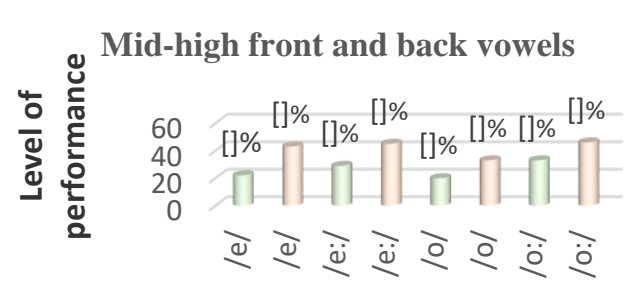

$$
\begin{aligned}
& \text { L1 - Light green } \\
& \text { L3 - Pink }
\end{aligned}
$$

Figure 4.2 Level of performance vowels in the second syllable

Figure 4.2 try to shows the level of performance of the participants in level 1 and level 3 in general.

Table 4.5 Performance summary of mid-high front and back vowels

\begin{tabular}{ccccccc}
\hline Syllable & $\begin{array}{c}\text { Mid- } \\
\text { high } \\
\text { Front }\end{array}$ & $p$ & Sig & $\begin{array}{c}\text { Mid- } \\
\text { high } \\
\text { Back }\end{array}$ & $p$ & Sig \\
\hline First & /e/ & .138 & No & /o/ & .063 & No \\
$\#$ & /e:/ & .001 & Yes & $/ \mathrm{o} / /$ & .006 & Yes \\
Second & $/ \mathrm{e} /$ & .001 & Yes & $/ \mathrm{o} /$ & .075 & No \\
$\#$ & /e:/ & .007 & Yes & /o:/ & .041 & Yes \\
\hline
\end{tabular}

The figures 4.1 and 4.2 show the performance levels of the two groups for the production of midhigh front and back vowels of Hausa.

\section{Substitution}

Substitution is one of the major types of phonological interference caused by the language contact phenomenon, and it also shows how target sounds are replaced with the equivalent sounds available in the learner's mother tongue to facilitate speech in a new language (Akinlabi, 2007). Accordingly, substitution tends to preserve sounds from deletion where a word is reshaped closer to the input form (Hock, 1991; Hussain, Mahmood \& Mahmood, 2011). In substitution, an item is replaced with the phonetically close phonemes in the recipient's language. Studies (e.g. Adekunle, 2014; Miao, 2005; and Ojo, 2004) have shown that in second language learning, a foreign phoneme either is replaced with the closest alternative sound or realised as an entirely different output. When sounds are substituted or realised as different phonemes in pronunciation, they all manifest some minimal changes at the segmental level (Adekunle, 2014; Broselow, 1999; Kenstowicz, 2007; Silverman, 1992; Ufomata, 2004).

In this section, vowel substitutions are presented in the substitution matrix (see Tables 4.6 to 4.9). Note. The vowel phones exclusive for Hausa have been underlined; vowel phones exclusive for Yorùbá were in italics, whereas shared vowel phones remained in bold. Phones used by Yorùbá speakers for substituting Hausa vowel phonemes (dash $=$ no substitution). Putting dash (-) in the substitution matrix refers to the correct pronunciation of Hausa phonemes by Yorùbá speakers in the study, which means there was no erroneous substitution. The frequency counts under level 1 participants, four and above, were considered absolute errors committed by the participants; and less than four were regarded as human errors. This figure represented $10 \%$ of 40 , the number of level 1 participants Creswell (2014). In the case of level 3 participants, the frequency counts of 5 and above were confirmed errors committed by the participants, while less than five were considered human errors, which happened by accident. Using five as the benchmark also represented $10 \%$ of 48 , being the number of level 3 participants. The following Tables illustrate the different substitutions according to the syllable in each group.

Table 4.6 Vowel substitution matrix for level 1 in the first syllable

Hausa and Yorùbá vowels combined

\begin{tabular}{|c|c|c|c|c|c|c|c|c|c|c|c|c|c|c|c|c|c|c|c|c|}
\hline & & \multicolumn{10}{|c|}{ Hausa and Yorùbá vowels combined } & \multicolumn{9}{|c|}{ Yorùbá vowels only } \\
\hline $\mathbf{S} / \mathbf{N}$ & $\begin{array}{l}\text { Hausa } \\
\text { Vowel }\end{array}$ & $\mathbf{i}$ & $\underline{\mathrm{i}}:$ & e & $\underline{\mathrm{e}}$ & $\mathbf{a}$ & $\underline{\mathrm{a}}:$ & $\mathbf{0}$ & $\underline{\mathrm{o}}$ & $\mathbf{u}$ & $\underline{\mathrm{u}}:$ & $\underline{\mathrm{ai}}$ & $\underline{\mathrm{au}}$ & $\varepsilon$ & o & $\tilde{l}$ & $\tilde{\varepsilon}$ & $\tilde{a}$ & $\tilde{\jmath}$ & $\tilde{u}$ \\
\hline
\end{tabular}

Yorùbá vowels only

1. 1 le/ $\mathbf{4}$

2. $/$ e:/ 2 - 12 
The error counts presented in the above table were converted into percentages, taking into account the most frequent occurrence from highest to the lowest in the ranking. As observed from the substitution matrix, a mid-high short, back and rounded vowel /o/ was substituted with the mid-high long, back, and rounded vowel [o:] 17 (43\%). The mid-high long, front and unrounded vowel /e:/ was replaced by a mid-high short, back, and unrounded vowel [e] 12
(30\%). Next, it can be seen that the mid-high short, front and unrounded vowel /e/ was substituted with a mid-high long, front and unrounded vowel [e:] 7 (18\%). A mid-high long, back and rounded vowel /o:/ was replaced with a mid-high short, back, and rounded vowel [o] $5(13 \%)$, while the mid-high short, front and unrounded /e/ was substituted with a high, short, front and unrounded [i] $4(10 \%)$.

Table 4.7 Vowel substitution matrix for level 3 in the first syllable

\begin{tabular}{|c|c|c|c|c|c|c|c|c|c|c|c|c|c|c|c|c|c|c|c|c|}
\hline \multicolumn{11}{|c|}{ Hausa and Yorùbá vowels combined } & \multicolumn{10}{|c|}{ Yorùbá vowels only } \\
\hline $\mathbf{S} / \mathbf{N}$ & $\begin{array}{l}\text { Hausa } \\
\text { Vowel }\end{array}$ & $\mathbf{i}$ & $\underline{\mathrm{i}}:$ & e & $\underline{\mathrm{e}}$ & a & $\underline{\mathrm{a}}:$ & $\mathbf{o}$ & $\underline{\mathrm{o}}:$ & $\mathbf{u}$ & $\underline{\mathrm{u}}:$ & ai & $\underline{\mathrm{au}}$ & $\varepsilon$ & ว & $\tilde{\imath}$ & $\tilde{\varepsilon}$ & $\tilde{a}$ & $\tilde{\jmath}$ & $\tilde{u}$ \\
\hline 1. & le/ & - & - & - & 5 & 2 & 4 & - & - & - & - & - & - & - & - & - & - & - & - & - \\
\hline 2. & le:/ & - & - & - & - & - & - & - & - & - & - & - & - & - & - & - & - & - & - & - \\
\hline 3. & $/ \mathrm{o} /$ & - & - & - & - & 1 & - & - & 28 & - & - & - & - & - & - & - & - & - & - & - \\
\hline 4. & /o:/ & - & - & - & - & - & - & - & - & - & 2 & - & - & - & - & - & - & - & - & - \\
\hline
\end{tabular}

Table 4.8 Vowel substitution matrix for level 1 in the second syllable

Hausa and Yorùbá vowels combined

Yorùbá vowels only

\begin{tabular}{|c|c|c|c|c|c|c|c|c|c|c|c|c|c|c|c|c|c|c|c|c|}
\hline $\mathbf{S} / \mathbf{N}$ & $\begin{array}{l}\text { Hausa } \\
\text { Vowel }\end{array}$ & $\mathbf{i}$ & $\underline{\mathrm{i}}:$ & $\mathbf{e}$ & $\underline{\mathrm{e}}$ & $\mathbf{a}$ & $\underline{\mathrm{a}}:$ & $\mathbf{0}$ & $\underline{\mathrm{o}}:$ & $\mathbf{u}$ & $\underline{\mathrm{u}}:$ & $\underline{\mathrm{ai}}$ & $\underline{\mathrm{au}}$ & $\varepsilon$ & $\partial$ & $\tilde{l}$ & $\tilde{\varepsilon}$ & $\tilde{a}$ & $\tilde{J}$ & $\tilde{u}$ \\
\hline 1. & /e/ & 3 & 4 & - & 9 & 1 & - & - & - & - & - & - & - & - & - & - & - & - & - & - \\
\hline 2. & /e:/ & - & 5 & 4 & - & - & 1 & - & - & 1 & - & - & - & - & - & - & - & - & - & - \\
\hline 3. & $/ \mathrm{o} /$ & - & - & - & - & - & - & - & 20 & - & - & - & - & - & - & - & - & - & - & - \\
\hline 4. & /o:/ & - & - & - & - & - & - & 1 & - & 1 & 3 & - & - & - & - & - & - & - & - & - \\
\hline \multicolumn{21}{|c|}{$\begin{array}{ll}\text { Considering the errors count observed from the } & \text { high long, front unrounded /e:/ was substituted with a } \\
\text { above table, the mid-high short, back and rounded } & \text { high, long, front and unrounded [i:] 5 (12.5\%). In } \\
\text { vowel /o/ was substituted with mid-high long, back, } & \text { addition, while the mid-high short, front unrounded } \\
\text { and rounded vowel [o:] } 20(50 \%) \text {. Regarding the /e/ } & \text { /e/ was mispronounced as [i:] } 4(10 \%) \text {, the mid-high } \\
\text { vowel, evidence showed that it was mispronounced as } & \text { long, front unrounded /e:/ was also replaced with a } \\
\text { [e:] } 9(22.5 \%) \text {. This group also evidenced that a mid- } & \text { high, long, front, and unrounded [i:] } 4 \text { (10\%). }\end{array}$} \\
\hline $\mathbf{S} / \mathbf{N}$ & $\begin{array}{l}\text { Hausa } \\
\text { Vowel }\end{array}$ & $\overline{\mathbf{i}}$ & i: & $\mathbf{e}$ & $\underline{\mathrm{e}}:$ & $\mathbf{a}$ & $\underline{\mathrm{a}}:$ & $\mathbf{0}$ & $\underline{\mathrm{o}}:$ & $\mathbf{u}$ & $\underline{\mathrm{u}}:$ & $\underline{\text { ai }}$ & $\underline{\mathrm{au}}$ & $\varepsilon$ & $\partial$ & $\tilde{l}$ & $\tilde{\varepsilon}$ & $\tilde{a}$ & 3 & $\tilde{u}$ \\
\hline 1. & /e/ & - & - & - & 3 & 2 & - & - & - & - & - & - & - & - & - & - & - & - & & - \\
\hline
\end{tabular}




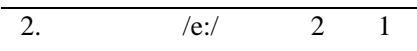

3.

4.

In a related development, as depicted in Table 4.9, only the substitution of /o/ vs /o:/ took centre stage in this group. However, as observed under serial number 3 , the mid-high, short, back, and rounded vowel /o/ was substituted with a mid-high, long, back, and
15

rounded vowel [o:] $15(31.3 \%)$. While 4 was $10 \%$ of 40 for level 1, 5 was $10 \%$ of 48 for level 3 participants. Table 4.10 below indicates vowels substituted with their frequencies in descending order.

Table 4.10 Substitution rank in descending order for the first and second syllables

\begin{tabular}{ccccccccc} 
& \multicolumn{4}{c}{ First syllable } & \multicolumn{3}{c}{ Second syllable } \\
Level 3
\end{tabular}

Table 4.11 Realisation of phonemes by the participants in level 1 and level 3

\begin{tabular}{|c|c|c|c|c|c|c|}
\hline & & \multicolumn{2}{|c|}{ Level 1} & \multicolumn{2}{|c|}{ Level 3} & \multirow[b]{2}{*}{ Nonreplaced vowel } \\
\hline $\mathbf{S} / \mathbf{N}$ & Hausa vowel & $\begin{array}{c}\text { First } \\
\text { syllable }\end{array}$ & $\begin{array}{l}\text { Second } \\
\text { syllable }\end{array}$ & $\begin{array}{c}\text { First } \\
\text { syllable }\end{array}$ & $\begin{array}{l}\text { Second } \\
\text { syllable }\end{array}$ & \\
\hline 1. & /e/ & [e:], [i] & [e:], [i:] & [e:] & $*$ & 1 \\
\hline 2. & /e:/ & [e] & [i:], [e] & $*$ & $*$ & 2 \\
\hline 3. & /o/ & [o:] & [o:] & [o:] & [o:] & 0 \\
\hline 4. & /o:/ & [o] & $*$ & * & $*$ & 3 \\
\hline
\end{tabular}

Table 4.11 summarises Hausa vowel phonemes and their realisation according to Yorùbá speakers'

pronunciations in level 1 and level 3 based on a syllable.

Table 4.12 Easy and difficult Hausa vowels for Yorùbá learners

Level 1

Level 3

\begin{tabular}{cccccccc}
\hline \multicolumn{2}{c}{ First syllable } & \multicolumn{2}{c}{ Second syllable } & \multicolumn{2}{c}{ First syllable } & \multicolumn{2}{c}{ Second syllable } \\
Easy & Difficult & Easy & Difficult & Easy & Difficult & Easy & Difficult \\
\hline- & /e/ & $/ \mathrm{o}: /$ & $/ \mathrm{e} /$ & $/ \mathrm{e} / /$ & $/ \mathrm{e} /$ & $/ \mathrm{e} /$ & $/ \mathrm{o} /$ \\
- & $/ \mathrm{e}: /$ & - & $/ \mathrm{e}: /$ & $/ \mathrm{o}: /$ & $/ \mathrm{o} /$ & $/ \mathrm{e}: /$ & - \\
- & /o/ & - & $/ \mathrm{o} /$ & - & - & $/ \mathrm{o} / /$ & - \\
- & $/ \mathrm{o}: /$ & - & - & - & - & - & - \\
$\mathbf{0}$ & $\mathbf{4}$ & $\mathbf{1}$ & $\mathbf{3}$ & $\mathbf{2}$ & $\mathbf{2}$ & $\mathbf{3}$ & $\mathbf{1}$ \\
\hline
\end{tabular}

Table 4.12 summarises the Hausa vowels, which were considered easy, and vowels that were also regarded as difficult for the Yorùbá native speakers to pronounce in disyllabic Hausa words in the first and second syllables. Meanwhile, Tables 4.13 and 4.14 below show that the first column contained the serial number. The second column displays the Hausa vowel phonemes. The next column shows the replaced vowels due to errors. The fourth column contains the Hausa words with the correct pronunciation and their real meaning, while the fifth column contains the wrong pronunciation as a result of vowel substitution by the participants, especially in the first and second syllables. Lastly, the sixth column displays the new meaning of the affected words after the substitution. Please note, Tables 4.13 and 4.14 showing * signifies 
vowel not substituted, and the meaning remained the same. ** refers to the vowels substituted, and yet words retained their meaning. These are illustrated in table

Table 4.13 Realised Hausa words by level 1 participants

\begin{tabular}{|c|c|c|c|c|c|c|c|}
\hline \multicolumn{8}{|c|}{ First syllable } \\
\hline $\mathbf{S} / \mathbf{N}$ & $\begin{array}{c}\text { Hausa } \\
\text { vowel }\end{array}$ & $\begin{array}{c}\text { Replaced } \\
\text { vowel }\end{array}$ & $\begin{array}{c}\text { Correct } \\
\text { pronunciation }\end{array}$ & $\begin{array}{c}\text { Real } \\
\text { meaning }\end{array}$ & $\begin{array}{c}\text { Learner } \\
\text { pronunciation }\end{array}$ & $\begin{array}{l}\text { Old/New } \\
\text { meaning }\end{array}$ & $\begin{array}{c}\text { Num. } \\
\text { replaced }\end{array}$ \\
\hline 1. & /e/ & [e:], [i] & /Kégé:/ & fish dorsal fin & $\begin{array}{c}\text { ** [ké:gé:], } \\
\text { [Kígé] }\end{array}$ & $\begin{array}{c}\text { fish dorsal fin } \\
-\end{array}$ & 2 \\
\hline 2. & le:/ & {$[\mathrm{e}]$} & /bé:bé:/ & $\begin{array}{c}\text { deaf and } \\
\text { dumb }\end{array}$ & **[bébé:] & deaf and dumb & 1 \\
\hline 3. & /o/ & [o:] & /dôkkí:/ & help & [dó:kí:] & - & 1 \\
\hline 4. & /o:/ & {$[\mathrm{o}]$} & /nó:má:/ & farming & **[nómá:] & farming & 1 \\
\hline \multicolumn{8}{|c|}{ Second syllable } \\
\hline 1. & /e/ & [e:], [i:] & /Ká:gé/ & allegation & $\begin{array}{c}\text { **[ká:gé:] } \\
\text { [ká:gí:] }\end{array}$ & $\begin{array}{c}\text { allegation } \\
-\end{array}$ & 2 \\
\hline 2. & /e:/ & {$[\mathrm{i}:],[\mathrm{e}]$} & /bè:gé:/ & appeal & [bè:gí:] **[bè:gé] & $\begin{array}{c}- \\
\text { appeal }\end{array}$ & 2 \\
\hline 3. & $/ \mathrm{o} /$ & [o:] & /Dó:gó/ & $\begin{array}{l}\text { name of } \\
\text { person }\end{array}$ & [dó:gó:] & tall/long & 1 \\
\hline 4. & /o:/ & $*$ & */nó:nò:/ & cow milk & *[nó:nò:] & cow milk & 0 \\
\hline
\end{tabular}

The above table shows the substituted vowels and the ones substituted with, in the first and second syllables according to the pronunciations of level 1 participants.

Table 4.14 Realised Hausa words by level 3 participants

\begin{tabular}{|c|c|c|c|c|c|c|c|}
\hline \multicolumn{8}{|c|}{ First syllable } \\
\hline $\mathbf{S} / \mathbf{N}$ & $\begin{array}{c}\text { Hausa } \\
\text { vowel }\end{array}$ & $\begin{array}{c}\text { Replaced } \\
\text { vowel }\end{array}$ & $\begin{array}{c}\text { Correct } \\
\text { pronunciation }\end{array}$ & $\begin{array}{c}\text { Real } \\
\text { meaning }\end{array}$ & $\begin{array}{c}\text { Learner } \\
\text { pronunciation }\end{array}$ & $\begin{array}{l}\text { Old/New } \\
\text { meaning }\end{array}$ & $\begin{array}{c}\text { Num. } \\
\text { replaced }\end{array}$ \\
\hline 1. & /e/ & [e:] & /Kégé:/ & fish dorsal fin & **[ké:gé:] & fish dorsal fin & 1 \\
\hline 2. & /e:/ & * & */bé:bé:/ & $\begin{array}{l}\text { deaf and } \\
\text { dumb }\end{array}$ & *[bé:bé:] & $\begin{array}{c}\text { deaf and } \\
\text { dumb }\end{array}$ & 0 \\
\hline 3. & /o/ & [o:] & /dồkí:/ & help & [do:kí:] & - & 1 \\
\hline 4. & /o:/ & $*$ & */nó:má:/ & farming & *[nó:má:] & farming & 0 \\
\hline & & & & Second syllable & & & \\
\hline 1. & /e/ & * & */ká:gé/ & allegation & *[ká:gé] & allegation & 0 \\
\hline 2. & /e:/ & $*$ & */bè:gé:/ & appeal & *[bè:gé:] & appeal & 0 \\
\hline 3. & $/ \mathrm{o} /$ & [o:] & /Dó:gó/ & $\begin{array}{l}\text { personal } \\
\text { name }\end{array}$ & [dó:gó:] & tall/long & 1 \\
\hline 4. & /o:/ & $*$ & */nó:nò:/ & cow milk & *[nó:nò:] & cow milk & 0 \\
\hline
\end{tabular}

The table above shows the vowels substituted and the ones substituted with in the first and second syllables. Considering the CV.C syllable arrangement within the same syllable, Table 4.13 (first syllable) involved the combination of 1 ejective plus 1 plosive sounds, 1 plosive plus 1 plosive sounds, 1 implosive plus 1 plosive sounds, as well as 2 nasal sounds, all with vowels between them (refer to serial number 1 4). Concerning the syllable arrangement of CV with another consonant across word morpheme, Table 4.14 (second syllable) therefore, comprised of 3 plosive sound plus the $/ \mathrm{k} /$, and 1 nasal plus the $/ \mathrm{k} /$ sound associated with the carrier phrase (... kuma) (see serial number $1-4)$. Formulating the results of the present study was to confirm the research problems so far identified.

\section{Discussion}

The data for the present study revealed that, except the mean rank for the Mann-Whitney $U$ test of /o/ ( $U$ $=49.30 \mathrm{vs} 40.50 ; p>.063)$, showing level 1 did better than level 3 participants in the first syllable, all other results indicated that level 3 participants performed better than level 1. These have been confirmed considering the mean ranks and the $p$ values for /e/ ( $\mathrm{U}$ $=41.00$ vs $47.42 ; p>.138)$, in the first syllable, as well as /o/ $(\mathrm{U}=40.00$ vs $48.25 ; p>.075)$ in the second syllable which were statistically non-significant. While the mean rank and the $p$ values for /e:/ $(\mathrm{U}=$ 37.40 vs $50.42 ; p<.001)$ in the first syllable indicated level 3 did significantly better than level 1 participants, and the two groups were not the same statistically, the results for /e/ $(\mathrm{U}=36.20$ vs $51.42 ; p$ $<.001)$, /e:/ $(\mathrm{U}=39.40$ vs $48.75 ; p<.007)$, /o:/ $(\mathrm{U}=$ 41.30 vs $47.17 ; p<.041)$ in the second syllable, as well as /o:/ $(\mathrm{U}=38.60$ vs $49.42 ; p<.006)$ in the first 
syllable all showed the performance of level 3 outperformed that of level 1 participants and they were statistically different (see Table 4.5). Some vowels were correctly produced by some participants, while other vowels were wrongly produced. The mispronunciation of L1 vowels by the L2 speakers has to do with differences in vowel inventory, leading to negative transfer.

Substitution, which is considered a change of unfamiliar phoneme(s) with the familiar sounds, occurs in many languages across the globe, including African languages (Hussain, Mahmood \& Mahmood, 2011; Kennedy, 2017). In this study, certain sounds were substituted with other vowels in the same environment. Meanwhile, participants' performance concerning vowel substitutions was discussed according to syllables, taking into account the pattern of substitution such as vowel shortening, vowel lengthening, and vowel raising.

\subsection{Substitution due to vowel shortening}

Substituting /e:/ with [e]: The participants' pronunciation in level 1 revealed how a mid-high, long, front and unrounded vowel /e:/ changed to a mid-high, short, front and unrounded [e] in the first syllable. As contained in the pronunciation of the participants, the /e:/ in Hausa word /bé:bé:/ (HH) was substituted with [e], thereby changing the pronunciation to [bébé:] (HH) 'deaf and dumb'. Such sound change was due to vowel shortening. The long Hausa /e:/ being shortened by Yorùbá speakers enable them to pronounce the Hausa word to the best they could, since /e:/ does not exist in Yorùbá. However, it may not be an underestimation if the pronunciation of a long /e:/ by the Yorùbá speakers is considered neither long nor short, but an intermediate since /e:/ does not exist in Yorùbá, but may exist as an allophone of /e/.

Similar to what was obtained in the first syllable, the pronunciation of level 1 participants in the second syllable, /e:/, was substituted with [e]. It was also regarded as vowel shortening, significantly where the vowel changed its quality from /e:/ to /e/. The pronunciation of the Hausa word changed from /bè:gé:/ (LH) to [bè:gé ' an appeal'. Even though the meaning was retained, the pronunciation has changed due to using the wrong vowel in the second syllable. This, therefore, has implications for the learning of Hausa as a second language, especially for the Yorùbá native speakers. (Note: a word-final vowel can be pronounced with an optional glottalic closure, which would shorten the [e] sound due to the first consonant of the next word in the carrier phrase.)

The results acquired concur with the study in Linda (2011), who disclosed the Igbo speakers learning English replace /3:/ with /e/ as in /girl/ [gel]. Similarly, Keshavarz and Khamis (2017) investigated the problems faced by Hausa native speakers when producing English vowels and revealed how English /3:/ was pronounced as /e/ in words such as / $\mathrm{girl} /$ with $40 \%$ frequency. This mispronunciation was due to negative transfer since /3:/ in English does not exist in Hausa. Adegbite \& Akindele (1999) discussed English learning by the Yorùbá speakers identified certain phonological items that show variation in the learners' speech. According to their study, there is a distinction between short and long vowels and changes in vowel qualities that are also responsible for the errors committed by the Yorùbá speakers pronouncing English words.

Substituting /o:/ with [o]: The long mid-high back-round Hausa vowel /o:/ erroneously substituted with the mid-high, short, back, and rounded [o] is best explained under vowel shortening process, especially between /o:/ vs /o/. It is also the case of a change in vowel quality where a mid-high, long back vowel /o:/ was made to become short [o] in the environment between nasal sounds $/ \mathrm{n} / \mathrm{vs} / \mathrm{m} /$. The phonetic approximation and changing the quality between long and short vowels explained why a significant number of Yorùbá speakers in level 1 in the first syllable pronounced /o:/ as [o]. Instead of the learners pronouncing the Hausa word Inó:má:/ (HH) 'farming', they mispronounced it as [nómá:] (HH) 'farming', thereby replacing the first syllable /o:/ with [o] despite the meaning remained the same. A similar result was discovered in Adekunle (2014), who investigated the foreign vowels in the speech-form of Yorùbá-English bilinguals. The study disclosed English /o:/ being substituted with [o] in the first syllable according to Yorùbá speakers' pronunciation of English word such as 'laws' for [los].

\subsection{Substitution due to vowel lengthening}

Substituting /e/ with [e:]: This study has established that /e/ was substituted with [e:] by participants in level 1 and level 3 according to their pronunciation in the first syllable. The Hausa word /kégé:/ (HH) 'fish dorsal fin' being mispronounced as [ké:gé:] (HH) 'fish dorsal fin' by the Yorùbá speakers affected only the pronunciation, but the meaning remained the same. This was due to the vowel lengthening, which changed the vowel from short to long. In Yorùbá, for instance, vowel length might fluctuate depending on the tonal environment. As such, Yorùbá speakers can pronounce a vowel either long or short since vowel length a times does not change the meaning.

Further, in the second syllable, participants in level 1 substituted /e/ with [e:] as contained in Hausa word /ká:gé/ (HH), which was mispronounced as [ká:gé:] 
$(\mathrm{HH})$ 'allegation'. Alternating /e/ with [e:] is also a case of vowel lengthening. Even though such vowel change did not influence the meaning of the affected word(s), the pronunciation has changed. More so that, Yorùbá does not have phonemic vowel length. In some cases, it does not change the meaning of a word, whether a vowel is pronounced short or long. The syllable-final vowels are pronounced long instead of short. This is why most learners pronounced /e/ instead of [e:] at the syllable-final position.

Substituting /o/ with [o:]: The substitution of /o/ with [o:] by the participants in level 1 and level 3 in the first syllable changed the pronunciation of Hausa word from /dôki:/ (FH) 'help/assistance' to [dó:kí:]

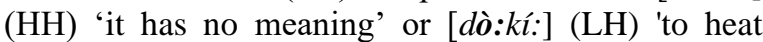
something/someone. In this regard, the replacement of /o/ with [o:] was due to vowel lengthening and change of vowel quality, from short to long. The two sounds have different duration in terms of their production. Some Yorùbá native speakers erroneously lengthen the short Hausa /o/ to [o:] despite the vowel length does not exist in Yorùbá. Supporting this argument, Fiyinfolu (2019) says vowel length or change in vowel quality is a contributing factor to the cause of intelligibility problem in second language learning ( $\mathrm{p}$. 201). The erroneous lengthening of short Hausa /o/ to [o:] by the Yorùbá learners may also be explained by a falling tone on /o/ in /dôki:/. Yorùbá does not have a falling tone, and the mistake indicates that Yorùbá speakers perceive a Hausa falling tone as more extended than a low or high tone, which causes them to lengthen the short $/ \mathrm{o} /$.

The pronunciation of level 1 and level 3 participants changed the Hausa /o/ to [o:] in the second syllable. Hausa word affected in this case is /Dó:gó/ (personal name), mispronounced as [Dó:gó:] (tall/long). Meanwhile, it was an issue of vowel length in the second syllable, as previously discussed. The meaning of the affected word changed from noun to adjective as a result of the vowel change. While the former is a noun, the latter is an adjective, and the noun is a derivative of the adjective. The lengthening of /o/ has to do with the word-final position, which tends to be pronounced long by default in Yorùbá. Supporting this discovery, Flege \& Bohn (2020) noted that shared sounds are always challenging to produce by L2 learners compared to the unshared sounds, hence, the replacement of /o/ with /o:/ in the second syllable.

\subsection{Substitution due to vowel raising}

Substituting /e/ with [i]: Replacing the mid-high, short, front, and unrounded vowel /e/ with the front, high, short, unrounded vowel [i] by level 1 participants in the first syllable can be discussed under vowel raising from /e/ to /i/. A raised vowel is a vowel phoneme in which, during the production, the body of the tongue is lifted or pushed towards the soft palate (Forghema, 2019). As observed in the present study, this affected the pronunciation of word such as /kégé:/ (HH) 'dorsal fish pin' to become [kígé:] $(\mathrm{HH})$ 'it has no meaning'. The result obtained is an instance being recorded in Kennedy (2017) where /e/ was realised as [i] as contained in the following English-Bemba word such as /endzIn/ mispronounced as [injini] 'engine'. According to Kennedy, it was a case of vowel adaptation, especially from another language. In a related development, Samson, Abdullahi, \& Olagunju (2014) revealed how Yorùbá speakers mispronounced English word due to vowel substitution. The pronunciation of English words by Yorùbá, changed from lezampul/ to [igzampl], was due to the substitution of /e/ with [i] the first syllable.

Substituting /e:/ with [i:]: As observed from data in the present research, it was discovered that in the second syllable, participants in level 1 substituted /e:/ with [i:]. This led to the change in the pronunciation of a word from /bè:gé:/ (LH) to [bè:gí:] (LH) 'it has no meaning'. Vowel raising from /e:/ to /i:/ took place where mid-high, long, front, unrounded vowel /e:/ changed to high, long, front unrounded vowel /i:/. The process caused the Yorùbá speakers to mispronounce /i:/ for /e:/.

Substituting /e/ with [i:]: Furthermore, in the second syllable, /e/ was substituted with the Hausa [i:] by participants in level 1 . This changed the pronunciation from /ká:gél (HH) 'allegation' to [ká:gí:] (HH) 'it has no meaning'. This is also a case of vowel raising from /e/ to /i:/ in the second syllable as observed in the data, where vowel raised from midhigh to the high position and vowel lengthening occurred the pronunciation of the participants as Yorùbá speakers.With the acute shortage of reading materials for the study of Hausa as a second language, the research serves as reference material to L2 teachers and learners. The study adds to the body of existing literature, particularly in linguistics and second language learning. Similarly, the research would also assist the Hausa language curriculum developers to redesign a new school curriculum by focusing more on vowels to minimise problems of mispronunciation, particularly in Hausa language learning. The present study's findings could assist Yorùbá native speakers to quickly identify and correct the mispronunciation they make when learning Hausa. It can significantly assist the Yorùbá native speakers to understand how to read and write in Hausa and speak the language fluently for inter-personal relation and socio-economic development.

Therefore, the methodology used in this study could assist researchers to carry out studies in other 
related African languages, such as in the area of syntax and morphology, which may not necessarily be in Hausa.

\section{Conclusion}

All the Hausa vowels were examined in pronunciation. Vowels such as /e/, /e:/, /o/, and /o:/ were generally identified as difficult vowels for the Yorùbá native speakers in level 1 to produce in the first syllable, while /e/ and /o/ were also difficult for them in the second syllable. Similarly, in the second syllable, apart from /o:/, which was easier to produce by the participants in level $1, / \mathrm{e} /, \mathrm{e}: /$, and /o/ were considered difficult for them in pronunciation. These resulted in the learners committing many errors in their pronunciation due to substitution. While level 3 participants considered $/ 0 /$ as a difficult vowel for them in the second syllable, /e/, /e:/, and /o:/, on the other hand, was easy to produce, especially in the pronunciation of disyllabic Hausa words (refer Table 4.12). However, the most frequent vowel substitution among the participants in level 1 in the first syllable included $/ \mathrm{o} / \rightarrow$ [o:], /e:/ $\rightarrow$ [e], while for $/ \mathrm{o} / \rightarrow[\mathrm{o}:]$ was the only one for the participants in level 3 . Similarly, in the second syllable, while /o/ $\rightarrow$ [o:], and /e/ $\rightarrow$ [e:] were considered more frequently substituted among the participants in level $1, / 0 / \rightarrow$ [o:] was more substituted compared to other vowels. Meanwhile, the substitution of /o/ with /o:/ was the only one that cut across the two groups both in the first and second syllables, whereas alternating /o/ with /o:/, and /e/ with /e:/ affected only the first syllable of level 1 .

Considering the experience/exposure of level 3 due to acculturation and teaching practice over their counterparts in level 1 made them commit fewer errors. Other linguistic reasons for the substitution identified in this study included shortening and lengthening of vowels and vowel raising. The outcome of this research is in line with the suggestions of Flege \& Bohn's (2020) 'Revised Speech Learning Model' (SLM-r) and Corder's (1967) 'Error Analysis Model'. Accordingly, while the 'Revised Speech Learning Model' predicts that shared sounds between the source and target languages are difficult to learn and produce by the L2 learners, the 'Error Analysis Model' says such sounds being shared are easier to produce compared to the unshared sounds, which are difficult for the participants, particularly in terms of second language (L2) learning. This is because individuals tend to transfer the forms and meanings of their native languages to the target language, especially when speaking or listening.

\section{Recommendations}

Teachers should make practical efforts early to aid students in identifying these problematic sounds and how to tackle them. The teachings should engage the attention of teachers at the appropriate levels. Students themselves should concentrate on these problem areas and devise means on how to tackle them. Teachers should also publish books that focus on these key areas to assist learners with reading materials.

\section{References}

Abdullahi, J. (2018). Cross-language perception and production of stops and fricatives among Malay and Hausa native speakers. Unpublished PhD thesis, Universiti Putra, Malaysia.

Abubakar, A. (1999). Depalatalisation in Hausa: A generative approach. Maiduguri Journal of Linguistics and Literary Studies, 1, 1-19.

Abubakar M. K. (2014). Pronunciation problems of Hausa speakers of English: The case of Nigerian students in North Cyprus. Unpublished M.A. thesis, Department of English Language Teaching, Near East University.

Abubakar, M. I., Maikanti, S. \& Ago, S. A. (2014). Hausa and English syllable structure for educational development. Police Academy Journal of English, Linguistics and French (POLACJELF), 1(2), 4-15.

Adegbite, W. \& Akindele, F. (1999). The sociology and politics of English in Nigeria: An introduction. Ile-Ife: OAU Press Limited.

Adejubee, S., \& Kammelu, N. C. (2010). Comparative study of the vowel harmony system (vhs) in Igbo and Yorùbá. Akungba Journal of Linguistics and Literatures, 1(2), 1-18.

Adekunle, O. G. (2014). Deviant Realization of Foreign Vowels in the Speech-Form of YorubaEnglish Nigerian Bilinguals. Open Journal of Modern Linguistics, 4(05), 720-727.

Akínkùgbé, O. O. (1978). A Comparative phonology of Yorùbá dialects; Ișẹkiri and Igala. Unpublished $\mathrm{PhD}$ thesis, Department of linguistics, University of Ibadan, Nigeria.

Akinlabi, A. (2007). Category change as vowel reduction. Proceeding. In The thirtieth Generative Linguistics in the Old World conference (GLOW XXX). Troms $\varnothing$, Norway.

Arokoyo, B. E. (2012). A comparative phonology of the Olùkùmi, Igala, Owe and Yorùbá languages. Paper presented for the International Congress "Towards Proto-Niger-Congo: Comparison and 
Reconstruction", Paris, 18-21 September 2012. pp. 10.

Ata, M. I. (2015). An acoustic study of Nigerian English vowels produced by Hausa speakers. Unpublished M.A. dissertation, University of Malaya, Malaysia.

Baba, A. T. (1998). The morpho-phonological alternations in the Hausa verbal form. Sonderforschungsbereich 268 an der JohannWolfgang-Goethe-Univ.Frankfurtam Main.

Babarinde, O. (2017). Nasalisation in Yorùbá: The Onko dialect perspective. Unpublished $\mathrm{PhD}$ thesis, Department of linguistics, Igbo and other Nigerian languages, University of Nsukka, Nigeria.

Blench, R. M. (2014). The origins of nominal affixes in MSEA languages: Convergence, contact and some African parallels. Languages of Mainland Southeast Asia: The State of the Art, 550-577.

Blench, R. M. (2019). An atlas of Nigerian languages 2019 edition. Cambridge CB1 A2 L, United Kingdom: McDonald Institute of Archiological Research.

Bargery, G. P. (1934). Hausa-English dictionary and English-Hausa vocabulary. London: Oxford University Press.

Broselow, E. (1999). Stress, epenthesis, and segment transformation in Selayarese loans. Annual Meeting of the Berkeley Linguistics Society, 25(1), 311-325.

Corder, S. P. (1967). "The significance of learners' errors". International Review of Applied Linguistics, 5, 160-170.

Creswell, J. W. (2014). Research design: Qualitative, quantitative and mixed methods approaches (4 ${ }^{\text {th }}$ ed.). London: Sage Publications Ltd.

Diettes, V. \& Johanna, K. (2014). Vowel reduction phenomena by Colombian-Spanish speakers of 12 English: An acoustic study. Forma $y$ Función, 27(1), 11-43.

Eberhard, D. M., Gary, F. S., and Charles D. F. (eds.) (2020). Ethnologue: Languages of the World. Twenty-third edition. Dallas, Texas: SIL International.

Eme, C. A., \& Uba, E. D. (2016). A contrastive study of the phonology of Igbo and Yorùbá, 17, 1-20. Online retrieved on 23/5/2018 from http://dx.doi.org//10.4314/ujah.v17i1.4.
Fagge, U. U. (2012). Hausa language and linguistics. Zaria, Nigeria: Amadu Bello University Press Ltd.

Federal Republic of Nigeria (2004). National policy on education. Abuja, Nigeria: Ministry of Education.

Fiyinfolu, I. (2019). Pronunciation intelligibility of Nigerian speakers of English. Unpublished $\mathrm{PhD}$ thesis, Department of Media, Culture and Language, University of Roehampton.

Flege, J. E., Bohn, O., \& Jang, S. (1997). Effects of experience on non-native speakers' production and perception of English vowels. Journal of phonetics, 25(4), 437-470. Online retrieved on 16/6/2018 from https://doi.org/10.1006/jpho.1997.0052.

Flege, J. E., \& Bohn, O. S. (2020). The revised speech learning model $(S L M-r)$. Online retrieved on 24/10/2020 from https://www.researchgate.net/publication/342923 320_The_revised_Speech_Learning_Model.

Forghema, N. I. (2019). Vowel alternations in the Kom language. BAJOLIN, 6(1), 106-128.

Ghauri, P. \& Gronhaug, K. (2005). Research methods in business studies. Harlow: Prentice Hall.

Gordon, R. G., Jr. (ed.), (2005). Ethnologue: Languages of the World, fifteenth edition. Dallas, Texas: SIL International. Online retrieved on 8/10/2018 from http://www.ethnologue.com/15.

Gwet, K. L. (2008). Computing inter-rater reliability and its variance in the presence of high agreement. British Journal of Mathematical and Statistical Psychology, 61, 29-48.

Hao, Y. C. (2012). Second language acquisition of Mandarin Chinese tones by tonal and non-tonal language speakers. Journal of phonetics, 40(2), 269-279.

Holten, E. H., \& Burnett, M. B. (1997). Qualitative research methods. In R. A. Swanson, \& E. F. Holton (Eds.), Human resource development research handbook: Linking research and prentice (pp. 623-649). San Francisco: Berrett-Koehler Publishers.

Hopkins, W. G. (2000). Quantitative research design. Sportscience, 4(1), 1-8.

Hussain, K., Mahmood, R., \& Mahmood, M. A. (2011). Vowel substitution: A comparative study of English loans in Punjabi and Urdu. International Journal of Linguistics, 3(1), $1-13$. 
Igboanusi, H. S. (2006). A comparative study of the pronunciation features of Igbo English and Yorùbá English speakers of Nigeria. English Studies, 87(4), 490-497.

Ilòrí, J. F. (2010). Yorùbá and French phonemics: Implications for FL teaching and learning. Journal of the Linguistic Association of Nigeria, 13, (2) 373-389.

Jaggar, P. (2001). A reference grammar of Hausa. Philadelphia Pennsylvania: John Benjamins.

Kennedy, K. N. (2017). Vowel substitution of English loanwords in Bemba. International Journal on Studies in English Language and Literature (IJSELL), 5(8), 30-41.

Kenstowicz, M. (2007). Salience and similarity in loanword adaptation: a case study from Fijian. Language Sciences, 29(2-3), 316-340.

Keshavarz, M. H. \& Khamis, A. M. (2017). An investigation into pronunciation problems of Hausa speakers, learners of English. International Online Journal of Education and Teaching (IOJET), 4(1), 61-72.

Koerich, R. D. (2002). Perception and production of word-final vowel epenthesis by Brazilian EFL students. Unpublished doctoral dissertation. Florianopolis: Universidade Federal de Santa Catarina.

Leben, W. R. (1970). The morphophonemics of tone in Hausa. U.S.: Eric IES Institute of Education Sciences.

Leung, A. (2008). Tonal assimilation patterns of Cantonese L2 speakers of Mandarin in the Perception and production of Mandarin tones. Unpublished $\mathrm{PhD}$ dissertation, University of Toronto.

Mahmoud, B. (2017). Phonological interference of Ebira in the Hausa spoken by Okene speech community. Unpublished M.A.

thesis,

Bayero University Kano, Nigeria.

Maiunguwa, A. (2015). Perception and production of English fricatives by Hausa speakers. Unpublished M.A. dissertation, University of Malaya, Kuala Lumpur, Malaysia.

Malah, Z. \& Rashid, S. Md. (2015). Contrastive analysis of the segmental phonemes of English and Hausa languages. International Journal of Languages, Literature and Linguistics, 1,(2), 106-112. Online retrieved on 11/10/2018. DOI:10.7763/IJLLL.2015.V1.21.
Mchugh, M. L. (2012). Inter-rater reliability: The kappa statistics. Biochemia Med (Zegreb), 22(3), 276-282.

Miao, R. Q. (2005). Loanword adaptation in Mandarin Chinese: Perceptual, phonological and sociolinguistic factors. $\mathrm{PhD}$ dissertation, Stony Brook, NY: Stony Brook University.

Migrant \& Seasonal Head Start Technical Assistance Center (2006). Introduction to data analysis handbook. Washington, D. $\quad$ C.: Academy for Educational Development.

Mohammed, K. B. (2011). Effects of mother tongue interference in second language acquisition: A case study of native Hausa learners of English language. Unpublished B.A. project, Department of English and French, Bayero University, Kano, Nigeria.

Newman, P. (1995). Hausa tonology: complexities in an 'easy' tone language. In J. Goldsmith (ed.), The handbook of phonological theory (PP. 762781). Cambridge, MA: Basil Blackwell.

Newman, P. (2000). The Hausa language: An encyclopedic reference grammar. New Haven: Yale University Press.

Ojo, G. A. (2004). A descriptive phonological study of the phonotactic constraints in the code- mixed Yorùbá-English bilingual lexicon. Unpublished $\mathrm{PhD}$ thesis, Ado-Ekiti, Ekiti State University, Nigeria.

Olusola, O. A. (2015). Comparative study of English and Yorùbá morphological system-implication for Nigerian teachers and learners of English. International Journal of English Language and Linguistic Research, 3(4), 18 .

Olúwadọrò, J. O. \& Abiloa, A. (2016). Olukumi: A dialect of Yorùbá in diaspora. Papers in English and Linguistics (PEL), 17, 320332.

Qin, Z., \& Mok, P. P. K. (2013). Discrimination of Cantonese tones by speakers of tone and non-tone languages. Kansas Working Papers in Linguistics 34. Online retrieved on 20/11/2019 from https://kuscholarworks.ku.edu/handle/1808/1286 4.

Salisu, T. \& Grema, M. (2018). A study of automatic assimilation and palatalisation in Bade language. Yobe Journal of Language, Literature \& Culture (YOJOLLAC), $\quad 6,102-109$. 
Samson, G. Y., Abdullahi, A., \& Olagunju, T. S. (2014). Mother tongue interference in the pronunciation of English sounds by Yorùbá language speakers. Academia. Edu. Online retrieved on 23/8/2020, 1-6.

Sani, M. A. Z. (2005). An introductory phonology of Hausa with exercises. Kano: Benchmark Publishers Limited.

Sani, M. A. Z. (2007). Tsarin sauti da nahawun Hausa. Ibadan: University Press.

Sharp, J. L., Mobley, C., Hammond, C., Withington, C., Drew, S., Stringfield, S., \& Stipanovic, N. (2012). A mixed-methods sampling methodology for a multisite case study. Journal of Mixed Methods Research, 6(1), 34-54.

Shehu, A., \& Njidda, I. U. (2016). Tone realisation in Hausa spoken by Fulfulde native speakers. Online retrieved on 5/10/2019 fromhttps://www.researchgate.net/publication/31 9306356.

Silverman, D. (1992). Multiple scansions in loanwords phonology: Evidence from Cantonese. Phonology, 9, 289-328.

Sloat, C., Hoard, J. E., \& Taylor, S. H. (1978). Introduction to phonology. Prentice-Hall.

So, C. K. (2010). Categorising Mandarin tones into Japanese pitch-accent categories: The role of phonetic properties. In a presentation at INTERSPECH 2010 satellite workshop on "Second Language Studies: Acquisition, Learning, Education and Technology". Tokyo, Japan.

So, C. K., \& Best, C. T. (2010). Cross-language perception of non-native tonal contrast: Effects of native phonological and phonetic influences. Language and Speech, 53(2), 273-293.

Tao, L., \& Guo, L. (2008). Learning Chinese tones: A developmental account. Journal of the Chinese Language Teachers Association, 43(2), 17-46.

Taherdoost, H. (2016). Validity and reliability of the research instrument; how to test the validation of a questionnaire/survey in a research. International Journal of Academic Research in Management (IJARM), 5(3), 28-36.

Thomson, R. I., \& Derwing, T. M. (2015). The effectiveness of L2 pronunciation instruction: A narrative review. Applied Linguistics, 36(3), 326344.

Ufomata, T. (2004). Tone and Stress in Contact: the example of English loanwords in Yoruball. Forms and Functions of English and Indigenous Languages in Nigeria. Ibadan: Ibadan City Group Publishers.

Wang, Y., Jongman, A., \& Sereno, J. A. (2003). Acoustic and perceptual evaluation of Mandarin tone productions before and after perceptual training. The Journal of the Acoustical Society of America, 113(2), 1033-1043.

Williamson, K. \& Blench, R. (2000). "Niger-Congo", in H. Bernd and N. Derek (Eds.) African Languages: An Introduction (PP. 11-42). Cambridge, UK: Cambridge University Press.

Wong, P., Schwartz, R. G., \& Jenkins, J. J. (2005). Perception and production of lexical tones by 3 year-old, Mandarin-speaking children. Journal of Speech, Language, and Hearing Research, 48, 1065-1079.

Wu, X., Munro, M. J., \& Wang, Y. (2014). Tone assimilation by Mandarin and Thai listeners with and without L2 experience. Journal of Phonetics, 46, 86-100.

Yang, C. (2019). The effect of L1 tonal status on the acquisition of L2 Mandarin tones. International Journal of Applied Linguistics, 29(1), 3-16.

Yusuf, O. (2007). Basic linguistics for Nigerian languages teachers. Port Harcourt: M \& J Grand Orbit Communication Ltd.

Zhang, H. (2007). A phonological study of second language acquisition of Mandarin Chinese tones. Unpublished M.A. thesis, University of North Carolina. 